\title{
DISTRIBUSI PANJANG TOTAL DAN KEBIASAAN MAKAN YUWANA IKAN PAYANGKA (Ophiocara porocephala)
}

\author{
Hendra Satria") dan Endi S. Kartamihardja")
}

\begin{abstract}
ABSTRAK
Danau Tondano terletak di Kabupaten Minahasa-Sulawesi Utara mempunyai luas perairan sebesar 4.600 ha dengan ke dalaman rata-rata $16 \mathrm{~m}$. Ikan payangka (Ophiocara porocephala) merupakan salah satu jenis ikan yang penangkapannya berlangsung sangat intensif mulai dari ukuran kecil (yuwana) sampai dewasa. Penangkapan ikan yang intensif tersebut jika tidak dikendalikan akan mengganggu kelestarian populasinya. Tujuan penelitian ini adalah untuk mendapatkan distribusi panjang yuwana ikan payangka dan kebiasaan makan. Distribusi panjang dianalisis dengan plot probabilitas (analysis probability plot), sedangkan makanan dan kebiasaan makan dianalisis menggunakan indeks preponderansi (preponderance index). Hasil penelitian menunjukkan bahwa yuwana ikan payangka di Danau Tondano terdiri dari 6 kelompok ukuran dengan rata-rata distribusi ukuran per kelompok masingmasing $18,05 \mathrm{~mm} ; 24,70 \mathrm{~mm} ; 30,22 \mathrm{~mm} ; 34,13 \mathrm{~mm} ; 39,86 \mathrm{~mm}$ dan $57,34 \mathrm{~mm}$. Makanan dan kebiasaan makan ukuran kelompok I sampai III (18,05-30,22 mm) adalah hampir sama. Makanan utama ukuran kelompok ukuran I sampai III adalah fitoplankton terutama dari jenis Navicula, Nitzchia, dan Ocillatoria, Phormidium dan Diatoma dan makanan pelengkapnya adalah zooplankton (Cyclpos, Nauplius, dan Brachionus). Pada kelompok ukuran IV $(34,13 \mathrm{~mm})$ menunjukkan sifat karnivor dan pada kelompok ukuran V $(39,86 \mathrm{~mm})$ sampai VI $(57,34 \mathrm{~mm})$ menunjukkan sifat karnivor dan kanibalisme. Data dan informasi ini dapat dimanfaatkan dalam rangka pengembangan pembenihan dan budi daya ikan payangka.
\end{abstract}

\section{ABSTRACT: Size distribution, food and feeding habits of payangka (Ophiocara porocephala) juvenile in Lake Tondano. By: Hendra Satria and Endi S. Kartamihardja}

Lake Tondano located in North Sulawesi is about 4,600 ha with an average depth of $16 \mathrm{~m}$. Payangka (Ophiocara porocephala) fish population that is one of the potential fishes in this lake was exploited intensively from the size of juvenil until adult. The intensive exploitation will effect on the sustainability of the payangka population. The aim of the present study was to investigate the size distribution of payangka juvenil and their food habits. Length distribution of payangka was analyzed using probability plot, while the gut content was analyzed using preponderance indexs. The result showed that the length distribution of payangka juvenil consist of 6 groups with an average size of each groups were $18.05 \mathrm{~mm}, 24.70 \mathrm{~mm}$, $30.22 \mathrm{~mm}, 34.13 \mathrm{~mm}, 39.86 \mathrm{~mm}$ and $57.34 \mathrm{~mm}$, respectively. Stomach content analysis showed that the size groups I $(18.05 \mathrm{~mm})$ until group III $(30.22 \mathrm{~mm})$ has the same pattem of food habits and was classified as plankton feeder. The main feeds of group I, II and III were phytoplankton Navicula, Nitzchia, Ocillatoria, Phormidium, and diatoma) and the additional feeds were zooplankton (Cyclops, Nauplius and Brachionus). The groups $V(34.13 \mathrm{~mm})$ was calssified as a camivorous and the group $V(39.86 \mathrm{~mm})$ and $\mathrm{VI}(57.34 \mathrm{~mm})$ are camivorous which tend to be cannibalisms.

\section{KEYWORDS : Ophiocara porocephala, juvenile, length distribution, food habit, and Lake} Tondano

\section{PENDAHULUAN}

Danau Tondano mempunyai luas perairan 4.600 ha dengan ke dalaman rata-rata $16 \mathrm{~m}$. Ikan payangka (Ophiocara porocephala) yang hidup di perairan Danau Tondano berasal dari perairan Danau Limboto, yang diintroduksikan pada tahun 1902 (Dinas Perikanan Kabupaten Minahasa, 1992) dan ikan tersebut berkembang dengan baik. Kelimpahan ikan payangka di perairan Danau Tondano belum diketahui dengan pasti. Penangkapan ikan payangka yang intensif dengan ukuran ikan yang tertangkap mulai dari yuwana sampai induk dikhawatirkan akan mengganggu kelestarian populasinya.
Cowx (1994) melaporkan bahwa makanan merupakan kunci pokok bagi pertumbuhan dan kelangsungan hidup ikan. Selanjutnya Nikolsky (1963) menyatakan bahwa kekurangan makanan merupakan faktor pembatas bagi perkembangan populasi ikan di perairan. Kebiasaan makan ikan dipengaruhi oleh beberapa faktor antara lain ukuran ikan dalam memanfaatkan makanan yang tersedia, habitat hidupnya, kesukaan terhadap jenis makanan tertentu, musim, ukuran dan umur ikan, periode harian mencari makan dan jenis kompetitor (Hickley, 1993). Analisis lambung ikan digunakan untuk mengetahui kebiasaan makan dan jenis pakan alami suatu jenis ikan pada ukuran tertentu. Nikolsky (1963) membedakan pakan ikan

\footnotetext{
"Peneliti pada Instalasi Perikanan Jatiluhur
} 
atas 3 kelompok yaitu pakan utama, pakan pelengkap dan pakan tambahan.

Soeroto (1990) dan Mondoringin (1980), menyatakan bahwa penelitian mengenai kebiasaan makan ikan payangka masih sedikit sekali. Meskipun demikian studi tentang ikan-ikan lain dari famili Eleotridae sudah cukup banyak dilakukan. Sebagai contoh, Nordlie (1981) melaporkan bahwa ikan dari famili ini bersifat karnivor. Ikan payangka diidentifikasi Akihito dan Toshino (1988) dan Kottelat et al. (1993) termasuk ke dalarn Gobiodea, Famili Eleotridae dan Genus (Ophiocara porocephala) (Gambar 1).

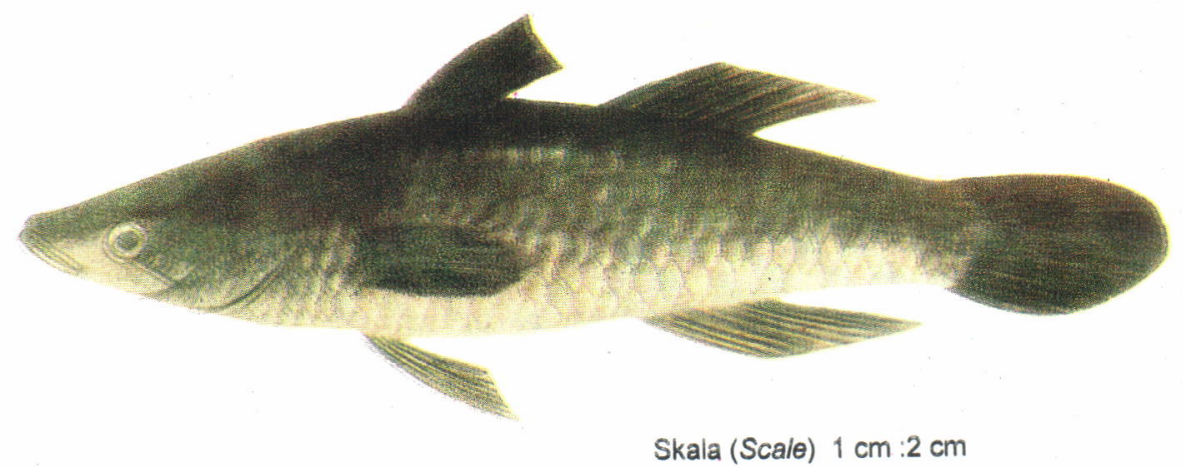

Gambar 1. Ikan payangka (Ophiocara porochepala)

Figure 1. Payangka (Ophiocara porochepala)

\section{BAHAN DAN METODE}

Metoda penelitian yang digunakan adalah metoda pengambilan contoh berstrata (stratified sampling method), (Nielson and Johnson, 1985). Untuk keperluan tersebut perairan Danau Tondano dibagi menjadi 5 stasiun pengamatan, yaitu stasiun I (Romboken), II (Kakas), III (P. Likri), IV (Touliang Oki), dan V (Toulour/outlet) (Gambar 2).

Ikan sampel ditangkap dengan alat anco (waring) dan seser. Yuwana ikan payangka dari hasil tangkapan nelayan tersebut diambil sebanyak $30 \%$ dari total, kemudian diambil lagi secara acak untuk dianalisis lebih lanjut sebanyak $30 \%$. Ikan sampel tersebut di masukan ke dalam kantong plastik dan diawetkan dengan formalin $10 \%$. Setiap individu ikan diukur panjang totalnya dan sebaran kelompok panjangnya dianalisis menggunakan paket program statistik (Wilkinson 1990), dengan cara membagi frekuensi panjang total ikan menjadi beberapa kelompok melalui analisis "probability plote" yaitu dengan melihat titik blok.

Tiap-tiap kelompok ukuran diperiksa kebiasaan makanannya dengan menggunakan metode reponderan (Natarajan dan Jhingran dalam Effendie, 1979).

Untuk mengetahul kelimpahan pakan alami yang tersedia di Danau Tondano dilakukan pengamatan terhadap jenis dan kelimpahan plankton, sedangkan sebagai data dukung dilakukan pula pengukuran beberapa parameter kualitas perairannya.

Sampel plankton diambil pada permukaan air, tengah, dan dasar perairan untuk tiap-tiap stasiun dengan alat Kemmerer Botle Sampler. Sampel air sebanyak 4 liter disaring dengan plankton net no.25, dimasukkan ke dalam botol plankton bervolume 20 $\mathrm{ml}$ dan kemudian diawetkan dengan formalin $5 \%$ sebanyak 2 tetes.

Pengamatan plankton dilakukan di laboratorium dan jenis plankton diidentifikasi menggunakan buku identifikasi Needham and Needham (1963) dan Edmonson (1959). Kelimpahan plankton dihitung berdasarkan metode Lackey Drop Microtransect Counting (Dirjen Pengairan, 1981) yaitu hasil penyaringan plankton di lapang pada 20 $\mathrm{ml}$ ini diaduk, dan sebagian kecil (3 tetes) di periksa di bawah mikroskop dengan 10 kali lapang pandang, untuk kemudian dieksplorasi perhitungannya ke dalam satu liter air.

Analisis kualitas air dilakukan di lapang (in-situ) dan di laboratorium. Pengamatan in-situ meliputi $\mathrm{O}_{2}$. $\mathrm{CO}_{2}, \mathrm{pH}, \mathrm{DMA}$ (Alkalinitas), suhu, kecerahan dan $\mathrm{ke}$ dalaman air. Metoda untuk pengamatan analisis kualitas air dilakukan dengan cara titrasi dan menggunakan alat DO meter 96, sechi disk, dan termometer. 


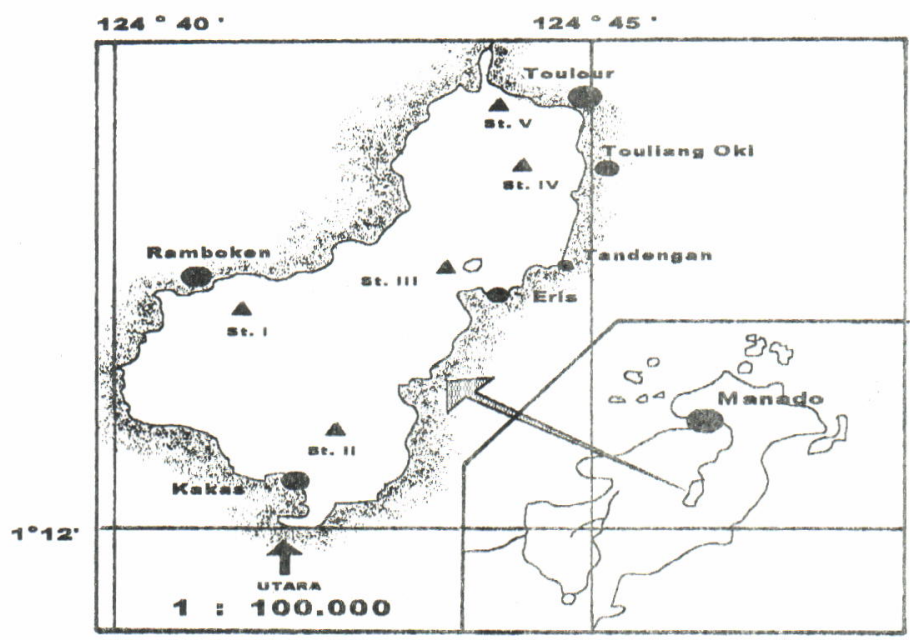

Gambar 2. Peta Danau Tondano dan stasiun pengamatan Figure 2. Map of Tondano Lake and the observation site

\section{HASIL DAN BAHASAN}

\section{Distribusi Panjang}

Hasil tangkapan menunjukkan bahwa ikan payangka yang diperoleh terdiri atas dua kelompok populasi (Gambar 3). Dua kelompok besar ini merupakan hasil pemijahan sebelumnya yang telah berkembang hingga mencapai ukuran besar. Hal ini disebabkan karena ikan payangka dapat berpijah 2 sampai 3 kali dalam satu kali musim pemijahan. Satria (1991a, 1991b) melaporkan bahwa pada umumnya jenis-jenis ikan tropis berpijah 2 sampai 3 kali selama satu musim pemijahan. Tiap-tiap kelompok hasil pemijahan berkembang dan menyesuaikan diri dengan lingkungannya. Dua kelompok ukuran tersebut adalah kelompok I dengan ukuran panjang total antara $140-195 \mathrm{~mm}$ Sedangkan hasil tangkapan juwana ikan payangka dari nelayan dengan menggunakan alat tangkap seser, juga menunjukkan adanya pemisahan kelompok. Analisis pemisahan kelompok juwana ikan payangka dengan probability plot terdiri dari 6 kelompok (Gambar 4).

Kelompok-kelompok ikan I ukuran ini, diduga sebagai hasil pemijahan pada waktu yang berlainan. Soeroto (1990) melaporkan bahwa ikan payangka dapat berpijah sepanjang tahun, dengan puncaknya bulan Juli, September, dan Desember. Dari hasil pemisahan tersebut, diperoleh kelompok I (K-1) berada pada kisaran 12-19 mm, kelompok II (K-2) dengan kisaran 20-25 mm, kelompok III (K-3) dengan kisaran 26-31 mm, kelompok IV (K-4) dengan kisaran 32-35 mm, kelompok $V(K-5)$ dengan kisaran 36-42 mm, dan kelompok $\mathrm{VI}(\mathrm{K}-6)$ dengan kisaran 60-66 mm.
Tiap kelompok yuwana ikan payangka terus berkembang, mulai dari kelompok I ke kelompok II dan seterusnya sampai ke kelompok VI. Selama perkembangan itu, termasuk pula kelompokkelompok yang berasal dari hasil pemijahan pada tahun yang sama. Setiap penambahan yuwana ikan payangka ini, akan membentuk suatu pupulasi yuwana ikan payangka yang baru dan seterusnya. Populasi yuwana ikan payangka dalam jumlah yang besar erat kaitannya degan keberadaan makanan ikan tersebut di perairan.

Kelompok yuwana ikan payangka yang terbesar berada pada kelompok ke-1 yaitu sebesar 526 ekor dengan panjang total rata-rata $18,05 \mathrm{~mm}$. Sedangkan kelompok ke-6 adalah merupakan kelompok yuwana ikan payangka yang terkecil dengan jumlah 11 ekor dan panjang total rata-rata $57.34 \mathrm{~mm}$ (Tabel 1 ).

Besarnya populasi yuwana ikan payangka pada kelompok-1 adalah hal yang wajar, di mana pada kelompok ini adalah merupakan kelompok yuwana ikan payangka yang masuk dari hasil pemijahan dengan jumlah yang besar, yang kemudian akan berkurang sejalan dengan bertambahnya umur dan ukuran yuwana tersebut, sebagai akibat dari persaingan makanan dan faktor lingkungan lainnya.

Berkurangnya populasi yuwana ikan payangka sampai kepada ukuran populasi ke 6 juga disebabkan oleh beberapa faktor, seperti faktor penangkapan (yang paling besar) dan faktor pemangsaan atau keseimbangan antara predator dan mangsa. Menurut Mess (1993) perbandingan yang seimbang antara ikan pemangsa (predator) 


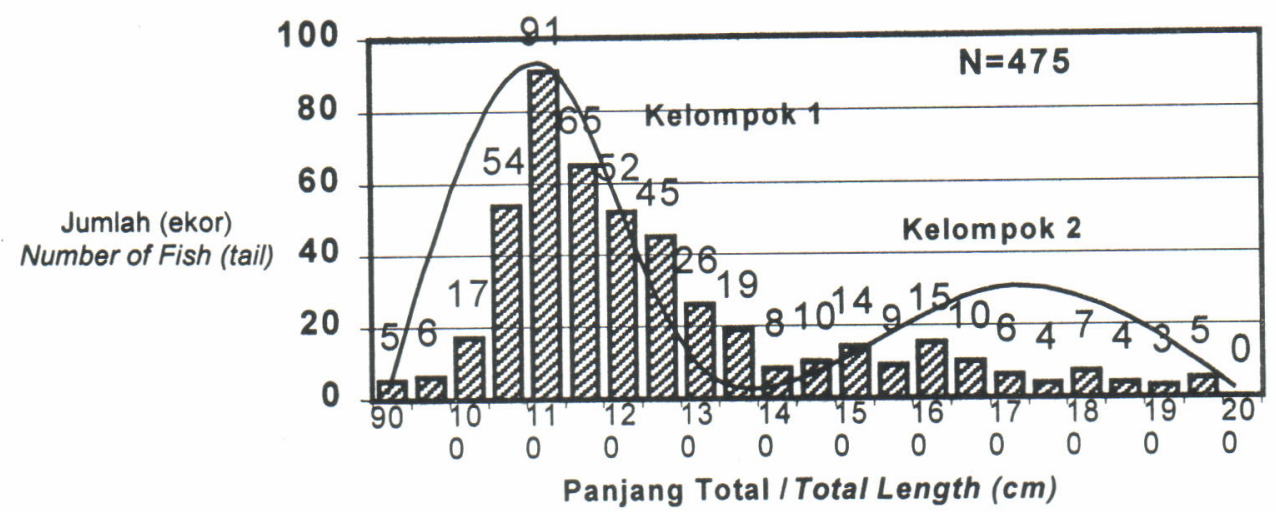

Gambar 3. Histogram sebaran panjang total ikan payangka (Ophiocara porochepaila) di perairan Danau Tondano

Figure 3. Histogram of length distribution of payangka (Ophiocara porochepala) in Tondano Lake

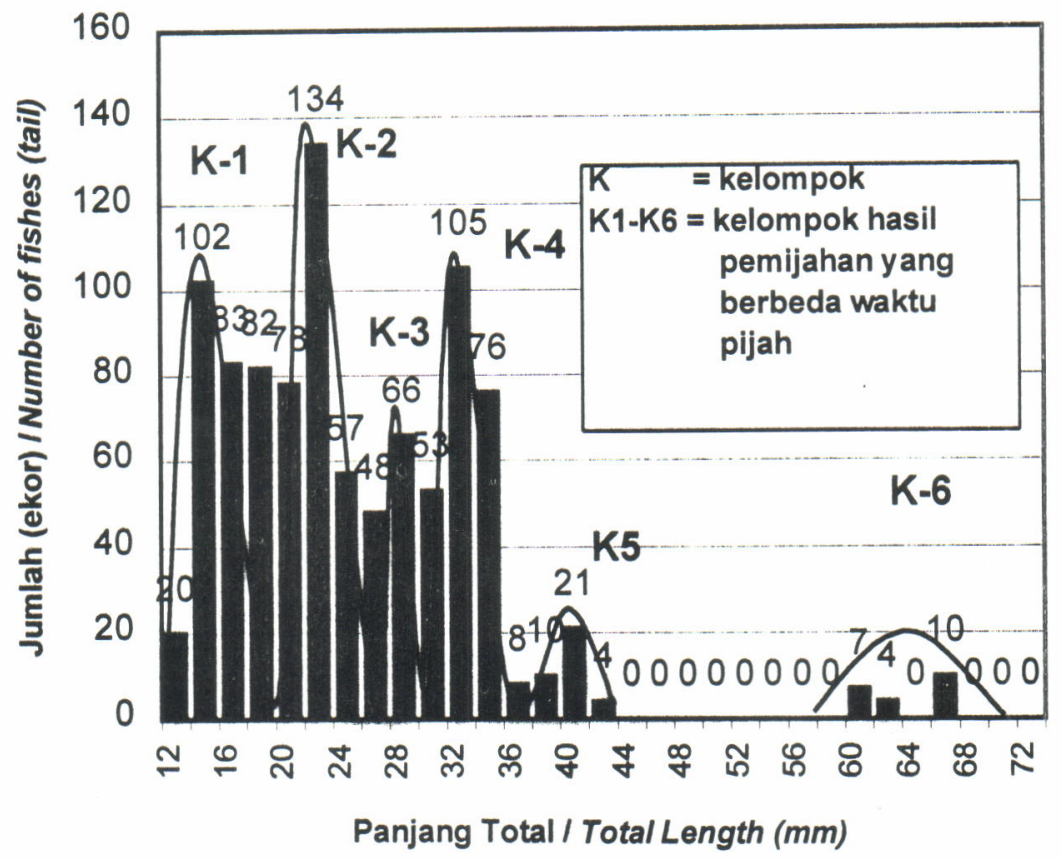

Gambar 4. Histogram sebaran panjang yuwana ikan payangka (Ophiocara porochepala) Figure 4. Histogram of length distribution of payangka (Ophiocara porochepala)

dan mangsa (prey) dalam suatu populasi ikan adalah 3:1. Predator yang ditemukan di perairan Danau Tondano terhadap yuwana ikan payangka adalah ikan lele (Clarias batrachus) dan gabus (Ophiocephalus striatus). Selain kedua jenis ikan tersebut, pemangsa adalah juga yuwana ikan payangka yang berukuran lebih besar. Hal ini dibuktikan dari hasil analisis lambung yuwana ikan payangka yang berukuran lebih besar, yaitu pada kelompok 5 dan kelompok 6 (Tabel 2). Fenomena kanibalisme ini dapat dijadikan salah satu acuan dalam pengembangan budi daya ikan payangka.

\section{Kebiasaan Makan}

Hasil analisis lambung yuwana ikan payangka menunjukkan bahwa makanan yuwana ikan payangka pada kelompok I (12,0-19,8 mm) sampai dengan kelompok III (27,6-31,4 mm) tidak berbeda, yaitu fitoplankton terutama dari jenis Navicula dan Nitzchia.Sedangkan makanan pelengkapnya adalah zooplankton terutama dari jenis Cyclops, Nauplius dan Brachionus, sehingga pada ukuran tersebut yuwana ikan payangka termasuk pemakan plankton (Tabel 2). 
Tabel 1. Analisis statistik sebaran panjang total yuwana ikan payangka (Ophiocara porochepala) di perairan Danau Tondano

Table 1. Statistical analysis for total length distribution of payangka (Ophiocara porochepala) juvenils in Lake Tondano

\begin{tabular}{lcccccc}
\hline \multicolumn{1}{c}{$\begin{array}{c}\text { Statistik } \\
\text { (Statistics) }\end{array}$} & \multicolumn{7}{c}{$\begin{array}{c}\text { Kelompok Panjang } \\
\text { (Length Groups) }\end{array}$} \\
\cline { 2 - 6 } & I & II & III & IV & V & VI \\
\hline $\begin{array}{l}\text { Jumlah sampel } \\
\begin{array}{l}\text { Number of sample } \\
\text { (individual) }\end{array}\end{array}$ & 526 & 210 & 121 & 74 & 20 & 11 \\
$\begin{array}{l}\text { Minimum } \\
\begin{array}{l}\text { Minimum } \\
\text { (mm) }\end{array}\end{array}$ & 12.00 & 20.40 & 27.60 & 31.50 & 36.10 & 42.40 \\
$\begin{array}{l}\text { Maksimum } \\
\begin{array}{l}\text { Maximum } \\
\text { (mm) }\end{array}\end{array}$ & 19.80 & 27.50 & 31.40 & 36.00 & 42.30 & 66.00 \\
$\begin{array}{l}\text { Rata-rata } \\
\text { Average } \\
\text { (mm) }\end{array}$ & 18.05 & 24.70 & 30.22 & 34.13 & 39.86 & 57.34 \\
$\begin{array}{l}\text { Simpangan baku } \\
\text { Standard deviation } \\
\text { (mm) }\end{array}$ & 2.590 & 1.99 & 1.525 & 1.158 & 1.828 & 8.588 \\
\hline
\end{tabular}

Pola kebiasaan makanan ikan payangka mulai berubah ke arah karnivor pada kelompok IV (31,5$36,0 \mathrm{~mm}$ ). Pada kelompok ini yuwana ikan payangka mulai memakan udang (Caridina sp). Udang yang ada di lambung ikan kelompok IV ini, masih merupakan makanan pelengkap. Diduga hal ini erat kaitannya dengan kelimpahan udang yang ada di perairan Danau Tondano yang cukup tinggi. Moukeke et.al. (1992) dan Opuszynski and Shireman (1993) melaporkan bahwa ukuran ikan dan kelimpahan pakan di perairan akan menentukan jenis dan komposisi pakan yang dimakan oleh ikan dan dapat merubah pola kebiasaan makanannya.

Yuwana ikan payangka pada kelompok $V$ dan VI pola makanannya lebih bervariasi, yaitu dengan memanfaatkan anak ikan, keong, dan udang. Dengan demikian yuwana ikan payangka pada ukuran panjang total rata-rata $39.86 \mathrm{~mm}$ sampai dengan $57.34 \mathrm{~mm}$ bersifat karnivor dan cenderung kanibal. Hal ini dibuktikan dari 29 ekor yuwana ikan payangka pada kelompok $\mathrm{V}$ dan $\mathrm{VI}$, terdapat 9 ekor yang lambungnya berisi yuwana ikan payangka yang besarnya kurang lebih sama dengan ukuran panjang total rata-rata pada kelompok I dan II (18.05-24.70 mm). Ibrahim dan Huntingkord (1992) melaporkan bahwa pada jenis ikan yang sama ikan mempunyai sifat kanibal, apabila kondisi di perairan tidak menguntungkan atau dengan kata lain pakan alami di perairan berkurang.
Yuwana ikan payangka pada kelompok $V$ sampai kelompok VI yang termasuk kelompok ikan karnivor dan bersifat kanibal ini didukung dengan ratio panjang saluran pencernaan yang relatif kecil, yaitu kurang dari $1 . \quad$ Nikolsky (1963) melaporkan bahwa panjang relatif saluran pencernaan untuk ikan karnivor adalah kurang dari 1, untuk ikan omnivor antara 1-3, sedangkan ikan herbivor jauh lebih besar yaitu antara 3-1.

\section{Kelimpahan Pakan Alami di Perairan}

Kelimpahan makanan yuwana ikan payangka erat hubungannya dengan ketersediaan plankton yang ada di perairan, di samping komposisi pakan yang dimakan oleh ikan. Letcher dan Benston (1993) melaporkan bahwa kelimpahan makanan di perairan akan mempengaruhi komposisi pakan yang dimakan oleh ikan. Kelimpahan plankton antar stasiun di Danau Tondano berkisar antara 10.59418.103 ind./l. Menurut klasifikasi Lander dalam Biotrop-Seameo (1983) perairan Danau Tondano termasuk perairan yang subur. Kelimpahan plankton yang tertinggi terdapat di stasiun IV (Touliang OKi) dengan rata-rata tiap kedalaman sebesar 6.034 ind./I dan kelimpahan terendah terdapat pada stasiun I (Romboken) dengan rata-rata tiap kedalaman sebesar 3.531 ind./l (Tabel 3).

Rendahnya kelimpahan plankton pada stasiun I (Romboken) diduga banyak dimanfaatkan oleh 
Tabel 2. Komposisi (\%) isi lambung yuwana ikan payangka (Ophiocara porocephala) menurut kelompok ukuran panjang totalnya.

Table 2. Stomach content composition (\%) of Ophiocara porochepala juvenils base on their total length groups.

\begin{tabular}{|c|c|c|c|c|c|c|}
\hline \multirow{2}{*}{$\begin{array}{l}\text { Jenis Makanan } \\
\text { (Foods items) }\end{array}$} & \multicolumn{6}{|c|}{$\begin{array}{c}\text { Kelompok } \\
\text { (Group) }\end{array}$} \\
\hline & $\begin{array}{c}\mathrm{l} \\
(18.05 \mathrm{~mm})\end{array}$ & $\begin{array}{c}\text { II } \\
(24.70 \mathrm{~mm})\end{array}$ & $\begin{array}{c}\text { III } \\
(30.22 \mathrm{~mm}) \\
\end{array}$ & $\begin{array}{c}\text { IV } \\
(34.13 \mathrm{~mm})\end{array}$ & $\begin{array}{c}V \\
(39.86 \mathrm{~mm})\end{array}$ & $\begin{array}{c}\mathrm{VI} \\
(57.34 \mathrm{~mm})\end{array}$ \\
\hline Phytoplankton & 56.9 & 53.2 & 55 & 45.3 & 36.9 & 36.0 \\
\hline $\begin{array}{l}\text { Chaetophora } \\
\text { Cladophora } \\
\text { Ulotrix } \\
\text { Zignema } \\
\text { Ocillatoria } \\
\text { Phormidium } \\
\text { Diatoma } \\
\text { Navicula } \\
\text { Nitzchia } \\
\end{array}$ & $\begin{array}{l}0.7 \\
1.1 \\
0.5 \\
0.5 \\
10 \\
1.8 \\
2.5 \\
20.3 \\
19.5 \\
\end{array}$ & $\begin{array}{c}0.5 \\
0.9 \\
0.7 \\
0.8 \\
10.5 \\
1.0 \\
1.5 \\
25.5 \\
11.8 \\
\end{array}$ & $\begin{array}{c}0 \\
0.8 \\
2.5 \\
1.5 \\
16.2 \\
2.9 \\
5.4 \\
14.0 \\
11.7 \\
\end{array}$ & $\begin{array}{c}0 \\
2.1 \\
1.7 \\
3.0 \\
16.4 \\
3.0 \\
0 \\
7.5 \\
11.6 \\
\end{array}$ & $\begin{array}{c}0.1 \\
3.0 \\
0 \\
2.1 \\
20.5 \\
4.9 \\
1.0 \\
3.5 \\
1.8 \\
\end{array}$ & $\begin{array}{c}0 \\
0.3 \\
0.1 \\
0 \\
10.1 \\
0 \\
0 \\
25.5 \\
0 \\
\end{array}$ \\
\hline Zooplankton & 43.1 & 46.8 & 45 & 48.7 & 50.1 & 43.5 \\
\hline $\begin{array}{l}\text { Cyclops } \\
\text { Nauplius } \\
\text { Brachionus } \\
\text { Keratella } \\
\text { Polyarthra } \\
\text { Asplanchna } \\
\end{array}$ & $\begin{array}{c}25.7 \\
5 \\
7.4 \\
3.5 \\
1 \\
0.5 \\
\end{array}$ & $\begin{array}{c}27.9 \\
5.5 \\
10 \\
1.4 \\
1.5 \\
0.5 \\
\end{array}$ & $\begin{array}{l}25.5 \\
2.5 \\
9.6 \\
3.7 \\
2.2 \\
1.5 \\
\end{array}$ & $\begin{array}{c}30.7 \\
3.5 \\
8.5 \\
6.0 \\
0 \\
0 \\
\end{array}$ & $\begin{array}{c}29.3 \\
5.7 \\
10.5 \\
2.5 \\
2.1 \\
0 \\
\end{array}$ & $\begin{array}{c}20.5 \\
5.8 \\
5.3 \\
11.0 \\
0.9 \\
0\end{array}$ \\
\hline $\begin{array}{l}\text { Lain-lain } \\
\text { Others } \\
\end{array}$ & 0 & 0 & 0 & 6 & 13 & 18.5 \\
\hline $\begin{array}{l}\text { ikan / fishes" } \\
\text { Keong } \\
\text { Mollusca }\end{array}$ & $\begin{array}{l}0 \\
0\end{array}$ & $\begin{array}{l}0 \\
0\end{array}$ & $\begin{array}{l}0 \\
0\end{array}$ & $\begin{array}{l}0 \\
0\end{array}$ & $\begin{array}{l}3.7 \\
2.1\end{array}$ & $\begin{array}{l}5.5 \\
3.7\end{array}$ \\
\hline $\begin{array}{l}\text { Udang } \\
\text { Shrimps } \\
\end{array}$ & 0 & 0 & 0 & 6.0 & 7.2 & 9.3 \\
\hline Total & 100 & 100 & 100 & 100 & 100 & 100 \\
\hline $\begin{array}{l}\text { Jumlah ikan sampel } \\
\text { Fish samples }\end{array}$ & 30 & 23 & 19 & 15 & 8 & 6 \\
\hline
\end{tabular}

yuwana ikan payangka di daerah tersebut. Karena pada daerah tersebut oleh Dinas Perikanan Kabupaten Minahasa digunakan sebagai tempat suaka ikan, walaupun perhatian untuk keadaan suaka ikan tersebut masih kurang serius.

Di Stasiun III kelimpahan plankton relatif sama dengan di stasiun II, namun rendahnya kelimpahan plankton di sini disebabkan oleh adanya arus dan gelombang air yang cukup kuat. Dengan kuatnya arus dan gelombang air ini, sehingga mikroorganisme seperti plankton akan terdistribusi ke daerah lainnya. Kelimpahan plankton di daerah DanauTondano didominasi oleh Chlorophyta terutama dari genus Protococcus, Selenastrum, Akistrodesmus, Crucigenia, Oedogonium, Zygnema, dan Sorastrum serta Baciliariophyta terutama dari jenis Navicula, Synedra, Melosira, Pinnularia, Cymbella, dan Nitzchia. Sedangkan dari zooplankton didominasi oleh divisio Rotatoria terutama dari genus Asplanchna, Brachionus, dan Keratella dan divisio Copepoda terutama dari jenis Cyclops dan Nauplius.

Hasil pengamatan kelimpahan plankton pada lapisan permukaan air, lapisan tengah dan lapisan dasar perairan Danau Tondano secara keseluruhan (stasiun I sampai stasiun 5), ditunjukkan pada Gambar 5. Beberapa fitoplankton, terutama dari Chlorophyta seperti genus Chaetophora, Cladophora, Zygnema, dan Cyanophyta. Phormidium, dan Ocillatoria yang terdapat di 
lapisan permukaan air, populasinya lebih kecil bila dibandingkan pada lapisan tengah maupun lapisan bawah. Hal ini disebabkan populasi algae benang yang ada pada lapisan atas tersebut banyak di manfaatkan oleh ikan dan anak ikan sebagai makanannya.
Pada stasiun I (Romboken) dan stasiun IV (Touliang Oki) kelimpahan populasi algae bening lebih kecil bila dibandingkan pada lapisan tengah. Karena pada stasiun ini merupakan tempat asuhan dan tempat mencari makan yuwana ikan payangka.

Tabel 3. Kemelimpahan plankton (individual/I) di Danau Tondano menurut stasiun dan kedalaman

Table 3. Plankton density (individual/) in Tondano Lake by station and depth

\begin{tabular}{|c|c|c|c|c|c|}
\hline \multirow{2}{*}{$\begin{array}{l}\text { Stasiun Pengamatan } \\
\text { (Observed Station) }\end{array}$} & \multicolumn{3}{|c|}{ Kolom Air (Water Column) } & \multirow{2}{*}{$\begin{array}{l}\text { Total } \\
\text { (Total) }\end{array}$} & \multirow{2}{*}{$\begin{array}{l}\text { Rata-rata } \\
\text { (Average) }\end{array}$} \\
\hline & $\begin{array}{c}\text { Atas } \\
\text { (Surface) }\end{array}$ & $\begin{array}{l}\text { Tengah } \\
\text { (Middle) }\end{array}$ & $\begin{array}{l}\text { Bawah } \\
\text { (Bottom) }\end{array}$ & & \\
\hline \multicolumn{6}{|l|}{ I.Romboken } \\
\hline Phytoplankton & 5,934 & 2.636 & 1,192 & 9,762 & 3,254 \\
\hline Zooplankton & 400 & 318 & 114 & 832 & 277 \\
\hline $\begin{array}{l}\text { Total Plankton } \\
\text { II.Kakas }\end{array}$ & 6,334 & 2,954 & 1,306 & 10,594 & 3,531 \\
\hline Phytoplankton & 9,311 & 3,200 & 1,457 & 13,968 & 4,656 \\
\hline Zooplankton & 1,137 & 959 & 140 & 2,236 & 745 \\
\hline $\begin{array}{l}\text { Total plankton } \\
\text { III.Pulau Eris }\end{array}$ & 10,448 & 4,159 & 1,597 & 16,204 & 5,401 \\
\hline Phytoplankton & 7,438 & 2,748 & 660 & 10,446 & 3,482 \\
\hline Zooplankton & 840 & 401 & 19 & 1,260 & 420 \\
\hline $\begin{array}{l}\text { Total plankton } \\
\text { IV.Touliang Oki }\end{array}$ & 7,878 & 3,149 & 679 & 11,706 & 3,920 \\
\hline Phytoplankton & 9,973 & 4,165 & 2,262 & 16,204 & 5,466 \\
\hline Zooplankton & 944 & 546 & 213 & 1,703 & 567 \\
\hline Total plankton & 10,917 & 4,711 & 2,475 & 18,103 & 6,034 \\
\hline V. Toulour & & & & & \\
\hline Phytoplankton & 8,718 & 4,329 & 1,526 & 14,573 & 4,857 \\
\hline Zooplankton & 633 & 369 & 169 & 1,171 & 390 \\
\hline Total plankton & 9,351 & 4,698 & 1,695 & 15,744 & 5,298 \\
\hline
\end{tabular}

\section{Lingkungan Perairan}

Persaingan makanan sesama ikan payangka, maupun antara ikan payangka dengan ikan lain di perairan Danau Tondano, dapat dikatakan sangat kecil. Dengan demikian keberhasilan ikan payangka dalam mengembangkan populasinya, antara lain karena ikan ini mempunyai luas relung yang lebar dan pakan yang tersedia di perairan melimpah.

Selain itu keberhasilan pemijahan dan fekunditas yang cukup besar, menyebabkan pula populasi ikan ini melimpah. Keberhasilan perkembangan populasi payangka ditunjukkan pula dengan banyak ditemukan yuwana ikan payangka di 5 lokasi pengamatan. Yuwana ikan payangka tersebut, hidup bergerombol pada suatu lokasi yang terlindung dari arus dan gelombang. Kelimpahan yuwana ikan payangka yang terbesar ditemukan di sepanjang garis pantai pada stasiun I, terutama daerah berteluk dan berbatu-batu, kemudian di daerah Pulau Likri dan sebagian di daerah pinggiran stasiun IV (Touliang Oki).
Suatu hal yang sangat mempengaruhi populasi yuwana ikan payangka adalah adanya kegiatan penangkapan yang berlebihan. Sampai saat ini, pengaruhnya dapat dilihat dari hasil tangkapan ikan payangka yang produksinya terus turun dari tahun ke tahun. Dinas Perikanan Kabupaten Minahasa (1992) melaporkan bahwa rata-rata hasil tangkapan yuwana ikan payangka dalam tahun 1980 sampai tahun 1985 adalah sebesar 8 ton dan hasil tangkapan tersebut menurun menjadi 2 ton pada tahun 1990.

Upaya pemerintah daerah setempat untuk melestarikan populasi ikan di Danau Tondano telah dilakukan melalui penetapan daerah suaka di Romboken. Namun demikian, di daerah suaka tersebut kegiatan penangkapan ikan terus berlangsung termasuk penangkapan ikan payangka. Kelimpahan yuwana ikan payangka yang begitu besar, membuat nelayan setempat berusaha untuk menangkap sebanyak-banyaknya, yaitu dengan membuat rumpon dari pelepah daun kelapa. Meskipun variasi jenis alat tangkap di 


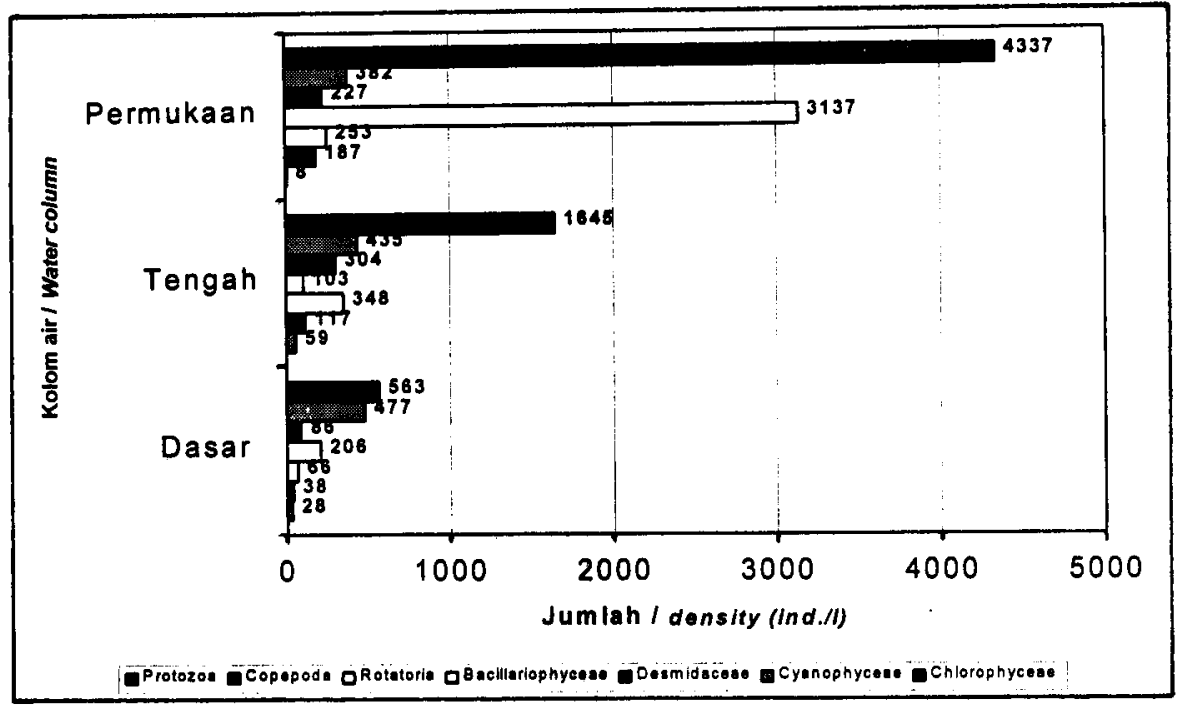

Gambar 4. Distribusi vertical kelimpahan plankton di perairan Danau Tondano Figure 4. Vertical distribution of plankton abundance in Tondano Lake
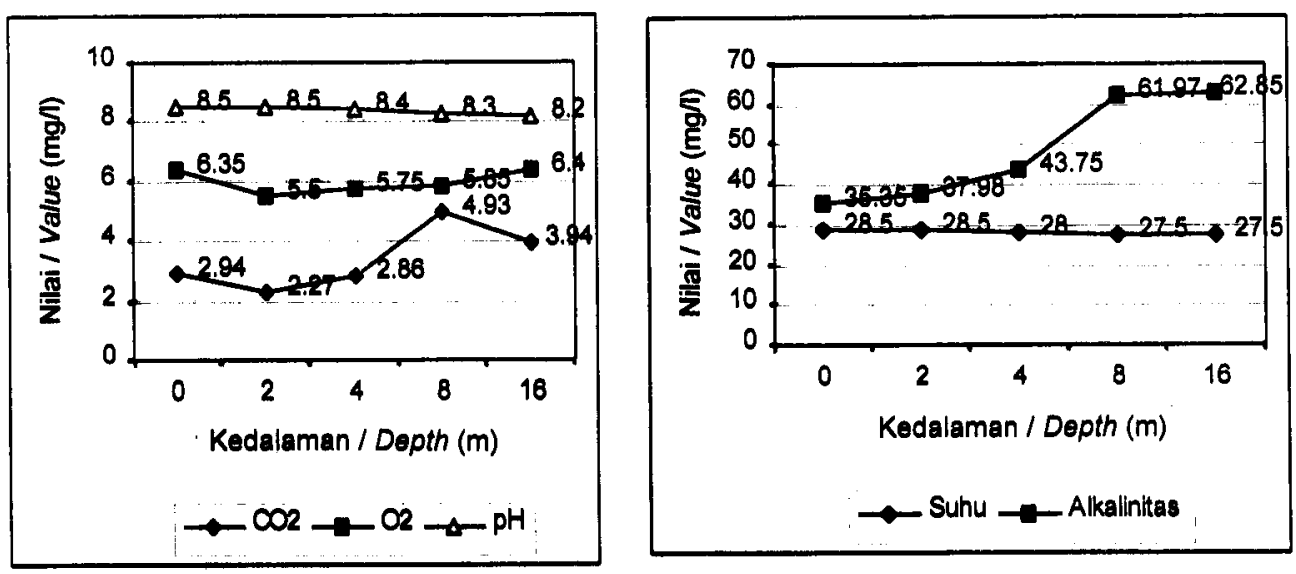

Gambar 6. Kualitas air di perairan Danau Tondano pada kedalaman air berbeda Figure 6. Water quality of Tondano Lake in different depth

perairan Danau Tondano tidak banyak, namun dari jumlah nelayan yang memanfaatkan potensi sumber daya perikanan dl danau ini cukup besar. Berdasarkan hasil pemantauan di lapang, setiap hari rata-rata jumlah nelayan yang menangkap yuwana ikan payangka dengan menggunakan seser di pinggiran danau ada sekitar 400 orang. Sedangkan jumlah nelayan yang ada di sekitar Danau Tondano, menurut laporan Dinas Perikanan Kabupaten Minahasa ada sekitar 1000 orang. Keadaan ini sudah tentu akan mengganggu populasi ikan, khususnya yuwana ikan payangka. Oleh sebab itu, peraturan tentang penangkapan ikan harus ditegakkan dan pelaksanaannya perlu diawasi.
Suaka perikanan (reservat) yang telah ditentukan oleh Dinas Perikanan Kabupaten Minahasa di daerah Romboken (Stasiun I), sebenarnya masih kurang tepat dan harus dipindahkan ke daerah lainnya yang lebih sesuai bagi perkembangbiakan dan pertumbuhan ikan yang dilindungi. $\mathrm{Hal}$ ini disebabkan daerah Romboken merupakan daerah objek wisata, sehingga dapat mengganggu populasi ikan di daerah tersebut. Penempatan suaka ikan haruslah berdasarkan kepada hasil penelitian yang seksama dan memperhatikan tata ruang pemanfaatan Danau Tondano. Suaka perikanan dapat ditetapkan di daerah antara Tasuka dan Taulimembet (Stasiun 2). 
Kualitas air di perairan Danau Tondano pada umumnya cukup baik untuk mendukung kehidupan ikan, baik ikan budi daya maupun ikan yang ada di perairan. Gambar 6 menunjukkan semua parameter yang di ukur di lapang $\left(\mathrm{O}_{2}, \mathrm{CO}_{2}\right.$, alkalinitas, dan $\mathrm{pH}$ ) dan kriteria tersebut yang mendukung kehidupan ikan dengan baik.

Kandungan $\mathrm{O}_{2}$ di permukaan sebesar $6,35 \mathrm{mg} / \mathrm{l}$ dan pada kedalaman $8 \mathrm{~m}$ sebesar $6,0 \mathrm{mg} / \mathrm{l}$. Keadaan ini sudah tentu baik untuk usaha budi daya KJA. Peningkatan produksi ikan dapat berhasil dengan penerapan teknologi KJA yang baik dan rencana yang matang.

\section{KESIMPULAN}

1. Populasi yuwana ikan payangka (Ophiocara porocephala) di perairan Tondano terdiri dari 6 kelompok, yang masing-masing kelompok terdiri dari hasil pemijahan yang berlainan. Ukuran panjang total rata-rata kelompok I $(18,05 \mathrm{~mm})$, kelompok II $(24,70 \mathrm{~mm})$, kelompok III $(30,22 \mathrm{~mm})$, kelompok IV $(34,13$ $\mathrm{mm})$, kelompok $\mathrm{V}(39,86 \mathrm{~mm})$, dan kelompok VI $(57,34 \mathrm{~mm})$. Populasi ikan payangka dapat menurun tajam, terutama yang disebabkan oleh penangkapan yang berlebihan, baik untuk ikan payangka yang berukuran besar maupun berukuran kecil (fingerling) yang disebut dengan nike.

2. Analisis isi lambung menunjukkan bahwa yuwana ikan payangka pada kelompok I sampai kelompok III adalah pemakan plankton (plankton feeder). Pada kelompok V sampai kelompok VI yuwana ikan payangka mempunyai sifat kanibalisme.

3. Kelimpahan pakan alami (plankton) di perairan Danau Tondano cukup besar, terutama dari famili Chlorophyceae seperti Protococcuc, Selenastrum, Akistrodesmus, Crucigenia, Oedogonium, Zygnema, Melosira, Pinnularia, Cymbella, dan Nitzchia. Kelimpahan plankton di seluruh perairan Danau Tondano berkisar antara 10.594-16.400 ind./l. Sedangkan kelimpahan rata-rata tiap kedalaman 3.5316.034 ind./l.

\section{DAFTAR PUSTAKA}

Akihito, P. Mayashi and T. Toshino. 1988. The Fishes of the Japanese Archipelago. $2^{\text {nd }}$ Edition. Tokyo Science Book. Pub. 445 pp.

Biotrop-Seameo. 1983. Penyelidikan Tanaman Air dan Perikanan Waduk pada Proyek. Irigasi Widas. Biotrop-Seameo. Bogor-Indonesia. 55 halaman.
Cowx, I.G. 1994. Stocking Strategis. Fisheries Management and Ecologi 1994.ICLARM. Makati Metro-Manila, Philippines. (1) 15-30 pp.

Dinas Perikanan Kabupaten Minahasa. 1992. Laporan Tahunan Perikanan Danau Tondano. 16 halaman.

Ditjen Pengairan. 1981. Pedoman Pengamatan Kualitas Air. Direktorat Penyelidikan.Masalah Air, Dirjen Pengairan Departemen Pekerjaan Umum. 265 halaman.

Edmonson, W.T. 1959. Freshwater Biology. Second Edition. John Willey and Sons, Inc $1248 p$

Effendie, M.I. 1979. Metode Biologi Perikanan. Yayasan Dewi Sri, Bogor. 112 hal.

Hickley, P. 1993. Stocking and Introduction of Fish a Synthesis. In: 1.G. Cowx (ed) The Rehabilitation of Freshwater Fisheries, Oxford. Fishing News Books, Blackwell Scientific Publication. pp 247-254.

Ibrahim, A. A. and F. A. Huntingkord. 1992. Experience of Natural Prey and Feeding Efficiency in Three Spined Stickleback (Gasterosteus aculatus L.). Journal of Fish Biology, 41(4): 619-625.

Kottelat, M., Antoni, J., Whitten., S.N. Kartikasari., dan S. Wirjoatrinojo. 1993. Ikan Air Tawar Indonesia Bagian Barat dan Sulawesi (edisi dwibahasa, Inggris-Indoriesia). 293 halaman.

Letcher, B.H. and Bengston, D.A. 1993. Effect of Density and Temperatur on Feeding and Growth of Young Inland Silversides (Henidia beryllina). Journal Fish Biologi, 43 (5): 671-686.

Mess, C.C. 1993. Population Biologi and Stock Assessment of Prispomoides Filamentous on the Mahe Plateau, Seychelles. Journal of Fish Biology, 43(5): 695-708

Mondiringin, L.J. 1980. Studi Tentang Makan dan Kebiasaan Makan, Alat-Alat Pencernaan, dan Selektifitas Makanan dari Ikan Nike (Ophiocara aporos Blkr) di Danau Tondano Sulawesi Utara. Thesis. Fakultas Perikanan Unsrat Menado.

Moukeke, M.I., Henry, C.C., and Moughan, O.E. 1992. Population Structure and Food Habits of White Capprie (Pomoxis annularis), in Turbid Oklahoma Reservoir. Journal Fish Biology, 41(4): 647-654.

Needham, J.G. and P.R. Needham. 1963. A Guide to the Study of Freshwater Biology. HoldenDay, Inc. San Francisco. 108 p.

Nielsen, L.A. and D.L. Jhonson. 1985. Fisheries Techniques. American Fisheries Society, Bethesda, Maryland. 486 pp. 
Nordlie, F.G. 1981. Feeding and Reproduktive Biology of Eleotrid Fishes in a Tropical Estuary. J. Fish Biol (18): 97-110.

Opuszynsky, K. and Shireman, J.V. 1993. Food Habit, Feeding Behavior and Impact of Triploid Big Head Carp (Hypopthalmus mobilis), in Experimental Ponds. Journal Fish Biology, 43(5): 517-530.

Nikoisky G.V. 1963. The Ecology of Fishes. Academic Press. New York. $325 \mathrm{p}$.

Satria, H. 1991a. Potensi Produksi Ikan Hampal (Hampala macrolepidota) di Waduk Saguling-
Jawa Barat. Bull. Penel. Perik Darat, 10 (1): 1016.

Satria, H. 1991b. Aspek Biologi Reproduksi Ikan Benteur (Puntius binotatus) dan Genggehek (Mystacoleucus marginatus) di Waduk CirataJawa Barat. Bull. Penel. Perik. Darat, 10 (2): 40-48.

Soeroto,B. 1990. Makanan dan Reproduksi Ikan Ophieleotris aporos (Bleeker) di Danau Tondano. Fakultas Pasca Sarjana-IPB. Thesis. Tidak Dipublikasikan. 187 halaman.

Wilkinson, L. 1995. SYSTAT: The System for Statistics. Evanston, IL.Systat, Inc. 560 p. 